\title{
Sistem Informasi Pengaduan Gangguan PDAM Tanah Laut Berbasis Web
}

\author{
Alivia Agiesta Novitasari ${ }^{1}$, Wan Yuliyanti ${ }^{2)}$ \\ Jurusan Teknik Informatika, Politeknik Negeri Tanah Laut \\ Jl. A. Yani Km 6 Pelaihari Tanah Laut Kalimantan Selatan \\ 1) aliviaagiesta06@gmail.com \\ 2)wanyuliyanti@politala.ac.id
}

\begin{abstract}
Abstrak
Perusahaan Daerah Air Minum (PDAM) Tanah Laut bergerak di bidang jasa pengelolaan dan penjualan air minum dengan jumlah pelanggan yang mencapai 7.848 yang tersebar di Kabupaten Tanah Laut. Pengaduan gangguan dilakukan oleh pelanggan secara manual kepada bagian hubungan langganan dengan datang langsung ke kantor PDAM Tanah Laut yang kemudian pengaduan tersebut akan didistribusikan kepada bagian teknik dan trandis. Berdasarkan masalah tersebut maka dibangun suatu sistem informasi pengaduan gangguan PDAM Tanah Laut berbasis web yang dapat memudahkan pelanggan melakukan pengaduan gangguan dan untuk memudahkan petugas dalam pendistribusian. Sehingga menghasilkan data pengaduan yang tepat dan efesien. Sistem informasi pengaduan gangguan PDAM Tanah Laut berbasis web ini dibangun dengan bahasa pemrograman PHP, HTML, CSS dan JavaScript. Serta dirancang menggunakan Entity Relationship Diagram dan Data Flow Diagram. Hasil pengujian blackbox menunjukkan bahwa seluruh fungsionalitas sistem berjalan dengan baik.
\end{abstract}

Kata kunci: sistem informasi, pengaduan gangguan, pelanggan.

\begin{abstract}
Tanah Laut Regional Water Supply Company (PDAM) is engaged in the management and sales of drinking water services with about 7,848 customers which spread throughout Tanah Laut Regency. Complaints of interference carried out by the customer manually to the customer relations department by coming directly to the office of the Tanah Laut PDAM which will then be distributed to the technical and distribution transmission. Based on these problems, a web-based PDAM Tanah Laut PDAM complaint information system is built that can make it easier for customers to make complaints of disturbances and to make it easier for officers to distribute it. This can produce accurate and efficient complaints data. This web-based information system for complaints of disturbance at PDAM Tanah Laut is built with programming languages PHP, HTML, CSS and JavaScript. And designed using Entity Relationship Diagrams and Data Flow Diagrams. The results of blackbox testing show that the functionalities of the system are perform properly.
\end{abstract}

Keywords: information systems, complaints of interference, customers

\section{PENDAHULUAN}

Perusahaan Daerah Air Minum (PDAM) Kabupaten Tanah Laut merupakan perusahaan jasa penyedia air milik Kabupaten Tanah Laut dengan 7.848 pelanggan yang tersebar di setiap desa yang ada di Kabupaten Tanah Laut. Setiap tahun pelanggan PDAM Tanah Laut selalu bertambah dengan berbagai macam spesifikasi jenis rumah tangga yang berbeda-beda. PDAM sebagai penyedia air terbesar di Kabupaten Tanah Laut dengan jumlah pelanggan yang banyak tentu 
membuat berbagai macam permasalahan terjadi setiap hari. Gangguan pelanggan terjadi setiap hari di berbagai daerah dengan berbeda-beda gangguan seperti pipa bocor, air macet dan lain-lain.

Berbagai masalah gangguan yang terjadi tidak hanya pada pelanggan PDAM tetapi juga bisa terjadi pada di saluran-saluran di pingggir jalan. Gangguan yang terjadi kemudian dilaporkan oleh pelanggan atau masyarakat yang mengetahui adanya gangguan ke bagian hubungan langganan (HUBLANG) dikantor PDAM Tanah Laut secara langsung yang kemudian akan dilakukan pencatatan gangguan yang telah dilaporkan oleh pelanggan lalu laporan itu akan dibuatkan surat perintah perbaikan (SPT) dan diserahkan ke bagian teknik untuk kemudian akan dilakukan perencanaan perbaikan. Selain datang langsung kekantor untuk melakukan pelaporan secara manual, pelanggan yang mengalami gangguan juga dapat melaporkan gangguan melalui telepon kantor. Namun karena sumber daya manusia (SDM) memiliki kekurangan terutama dalam hal ingatan, terkadang gangguan yang dilaporkan tidak tercatat dan tidak terproses oleh petugas.

Melihat adanya kelemahan pada sistem tersebut maka penulis mencoba membangun suatu sistem informasi pengaduan gangguan PDAM Tanah Laut berbasis web yang digunakan secara online yang dapat diakses melalui smartphone oleh pelanggan yang kemudian data yang dikirim oleh pelanggan akan masuk ke komputer admin hubungan langganan atau lebih dikenal dengan HUBLANG yang kemudian akan dilakukan transaksi dan data dikirim ke komputer bagian teknik untuk dilakukan perencanaan perbaikan. Data yang masuk melalui sistem ini, akan diperiksa kembali oleh petugas kebenarannya agar tidak terjadi kesalahpahaman. Setelah data diketahui akurat, maka data tersebut akan diproses sesuai sistem yang berjalan agar dapat ditindak lanjuti oleh bagian teknik untuk melakukan perbaikan. Diharapkan dengan adanya sistem ini dapat membantu pelanggan untuk melaporkan gangguan tanpa harus datang kekantor dan memudahkan admin HUBLANG untuk melakukan transaksi dengan bagian admin teknik.

\section{TINJAUAN PUSTAKA}

Menurut Kadir (2014) sistem informasi mencakup sejumlah komponen (manusia, komputer, teknologi informasi dan prosedur kerja), ada sesuatu yang diproses (data menjadi informasi), dan dimaksudkan untuk mencapai suatu sasaran atau tujuan. Salah satu jenis dari sistem informasi adalah sistem informasi pengaduan. Sistem informasi pengaduan adalah sistem informasi yang ditujukan untuk mempermudah proses pengaduan dari masyarakat atau entitas tertentu ke suatu institusi atau organisasi.

Latar belakang dibangunnya sistem informasi pengaduan sangat beragam. Boylle dan Arninputranto (2014) mengembangkan sistem informasi pengaduan di PELINDO III Cabang Tanjung Perak dikarenakan wilayah kerja yang luas dan hand over job yang tidak optimal. Sehingga pengawasan menjadi kurang karena susahnya pengaduan secara manual. Sulitnya pengaduan manual juga menjadi latar belakang bagi Pratama, Prabowo dan Normassari (2017) dalam mengembangkan aplikasi pengaduan untuk melaporkan pungutan liar di Kabupaten Kudus.

Selain permasalahan wilayah yang luas, efektifitas waktu juga menjadi pertimbangan dalam pembangunan sistem layanan pengaduan (Firmansyah \& Tohir, 2018). Ibrahim dan Maita (2017) melakukan pengembangan sistem informasi pelayanan publik di Dinas PU Kabupaten Kampar juga dikarenakan pelayanan yang ada masih kurang efektif dan efisien.

PDAM merupakan perusahaan yang sangat terkait dengan pengaduan. Penelitian yang dilakukan Nofyat, Ibrahim dan Ambarita (2018) tentang sistem informasi pengaduan pelanggan di PDAM Kota Ternate berlatar belakang pada waktu pengaduan yang hanya dilakukan pada hari Senin sampai Jum'at pada pukul 07.30 - 15.00 WITA. Pembatasan waktu tersebut dianggap menyebabkan pengaduan menjadi kurang efektif. Penelitian yang dilakukan oleh Almuqistu, Tursina dan Sukamto (2019) tentang pengembangan aplikasi pelayanan pelanggan PDAM Tirta Kapuas sudah dapat menjawab berbagai macam permasalahan mengenai pelayanan pelanggan, dimana salah satunya adalah tentang pengaduan. Dari kuesioner yang disebarkan didapatkan bahwa sebesar 94,5\% responden setuju bahwa aplikasi tersebut dapat mengatasi permasalahan yang terkait dengan pelayanan pelanggan. 


\section{METODE PENELITIAN}

\subsection{Kerangkan Penelitian}

Penelitian dilakukan dengan melakukan pengumpulan data, yaitu studi literatur, wawancara dan observasi langsung ke PDAM Tanah Laut. Setelah data dikumpulkan kemudian dilakukan analisis kebutuhan sistem, perancangan dan implementasi perancangan ke dalam bahasa pemrograman. Perancangan yang dilakukan adalah perancangan database dengan menggunakan ERD dan perancangan aliran data menggunakan DFD. Setelah itu sistem diuji fungsionalitasnya menggunakan blackbox testing. Kerangka penelitian digambarkan pada Gambar 1.

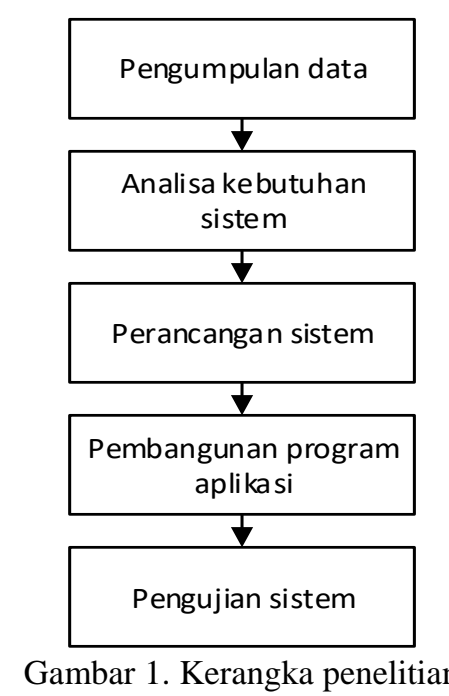

\subsection{Model Pengembangan Perangkat Lunak}

Model yang digunakan dalam mengembangkan sistem informasi pengaduan gangguan PDAM Tanah Laut adalah model waterfall. Model ini dipilih karena pendekatan sekuensial dari waterfall sesuai dengan kebutuhan pengembangan dari sistem informasi yang dibangun, yaitu analisa kebutuhan sistem dilakukan terlebih dahulu, kemudian mendesain, membuat kode program dan melakukan pengujian. Model waterfall ditunjukkan pada gambar 2.

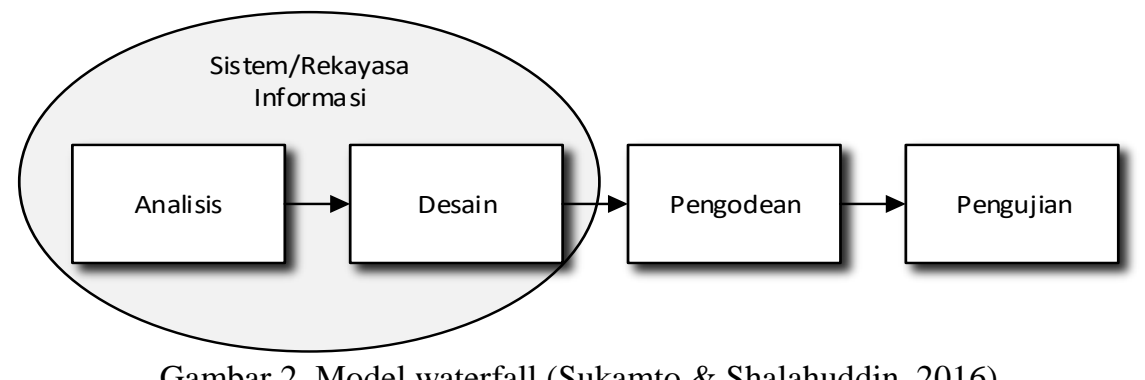

Gambar 2. Model waterfall (Sukamto \& Shalahuddin, 2016)

\section{HASIL DAN PEMBAHASAN}

\subsection{Analisa Kebutuhan Sistem}

Sistem pengajuan pengaduan yang sudah berjalan pada PDAM Tanah Laut adalah sebagai berikut:

1. Pelanggan datang kekantor untuk melakukan laporan gangguan yang terjadi.

2. Setelah laporan pelanggan masuk maka bagian hubungan langganan (HUBLANG) akan mencatat gangguan yang terjadi dan membuat surat perintah perbaikan (SPP).

3. SPP akan diserahkan ke kepala bagian teknik.

4. Kemudian SPP akan diberikan ke bagian Transmisi Distribusi (TRANDIS). 
Sistem informasi pengaduan yang akan dibangun memuat kebutuhan sebagai berikut:

1. Pelanggan mengadukan gangguan melalui sistem informasi secara online.

2. Bagian HUBLANG menerima informasi dari sistem mengenai pengaduan yang telah dilakukan.

3. Data pengaduan diberikan nomor SPP oleh bagian HUBLANG.

4. Bagian Teknik menerima informasi pengaduan gangguan yang telah diberikan nomor SPP dari sistem.

5. Bagian Teknik menentukan skala prioritas dari pengaduan gangguan.

6. Bagian TRANDIS mendapatkan informasi pengaduan gangguan beserta skala prioritas dari sistem.

7. Bagian TRANDIS menginputkan tanggal perbaikan dan keterangan perbaikan yang dilakukan pada data pengaduan gangguan.

\subsection{Perancangan Sistem}

Sistem informsi pengaduan gangguan PDAM Tanah Laut dirancang dengan Entity Relationship Diagram (ERD) dan Data Flow Diagram (DFD):

\subsubsection{Entity Relationship Diagram (ERD)}

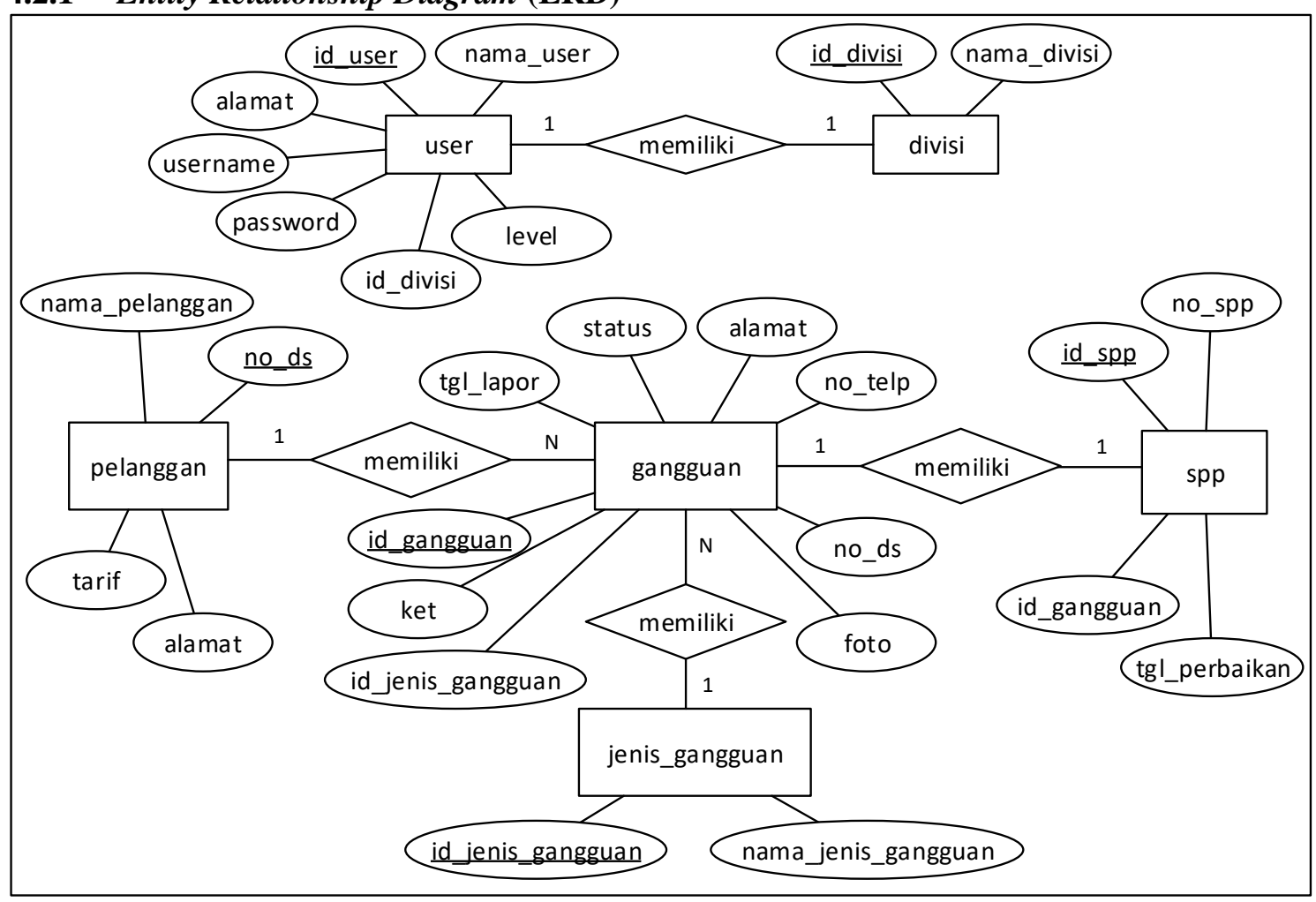

Gambar 3. Entity Relationship Diagram

Gambar 3 menjelaskan tentang diagram ERD dimana terdapat beberapa entitas yang saling berhubungan. Entitas pertama merupakan entitas user yang memiliki entitas id_user sebagai primary key, username, password, nama_user dan level. Kemudian entitas divisi yang memiliki atribut id_divisi sebagai primary key dan nama_divisi. Entitas pelanggan memiliki atribut nama_pelanggan, no_ds, alamat dan tarif, entitas gangguan memiliki atribut id_gangguan sebagai primary key, no_ds sebagia foreign key, id_jenis_gangguan sebagai foreign key, no_telp, alamat, status, ket, foto, tgl_lapor. Entitas jenis_gangguan dengan atribut id_jenis_gangguan sebagai primary key dan nama_gangguan. Entitas spp dengan atribut id_spp sebagai primary key, id_gangguan sebagai foreign key, no_spp dan tanggal perbaikan. 


\subsubsection{DFD Level 0 (Diagram Konteks)}

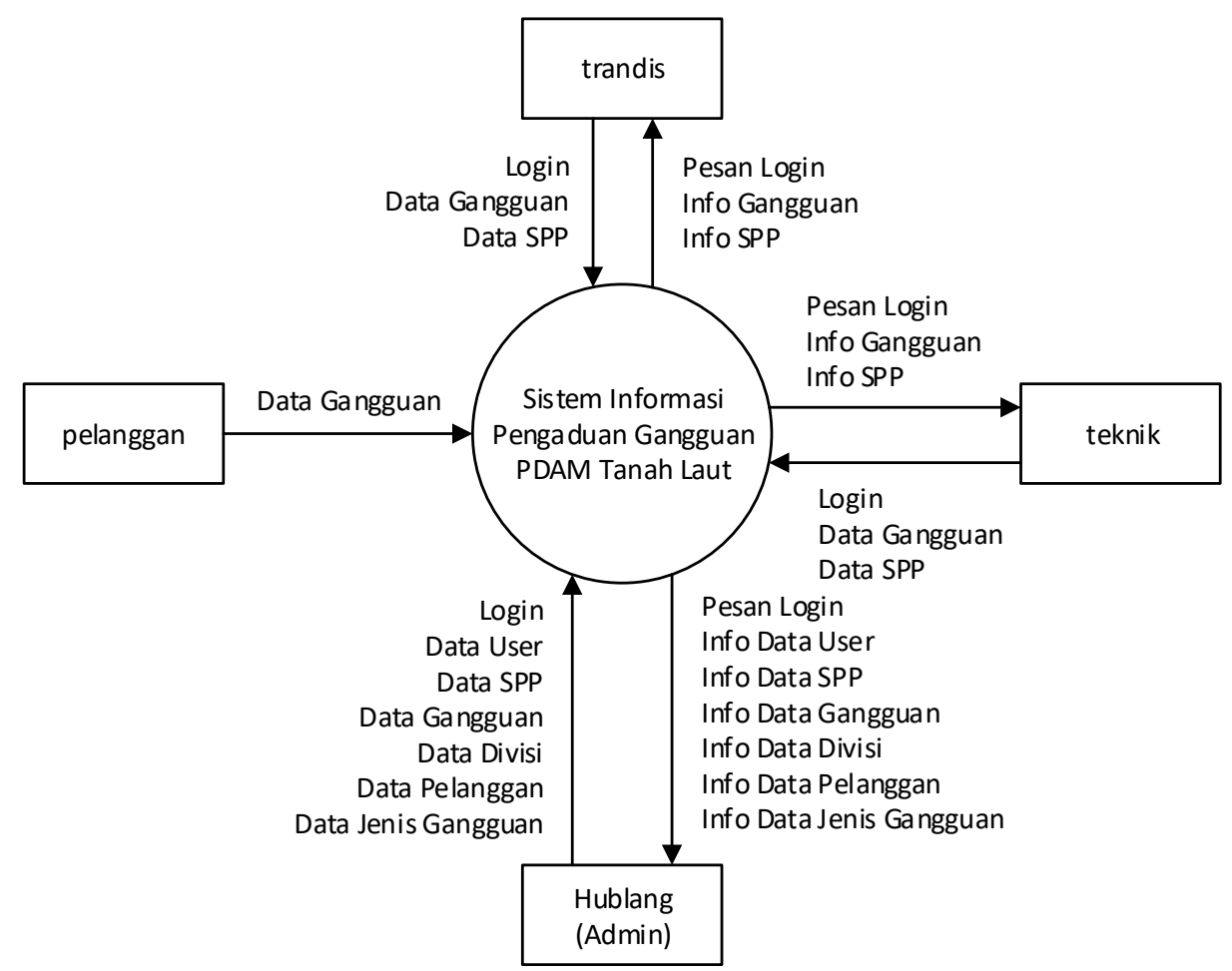

Gambar 4. DFD Level 0 (diagram konteks)

Gambar 4 merupakan gambaran DFD level 0 atau diagram konteks atau awal dari pembuatan rancangan DFD. Diagram konteks menjelaskan tentang aliran data suatu sistem. Diagram konteks ini menjelaskan tentang Sistem Informasi Pengaduan Gangguan PDAM Tanah Laut yang memiliki 4 entitas pelaku yaitu pelanggan, HUBLANG, teknik dan TRANDIS. Setiap entitas pelaku memiliki hak akses masing-masing.

\subsection{Implementasi}

\subsubsection{Halaman Beranda Free User}

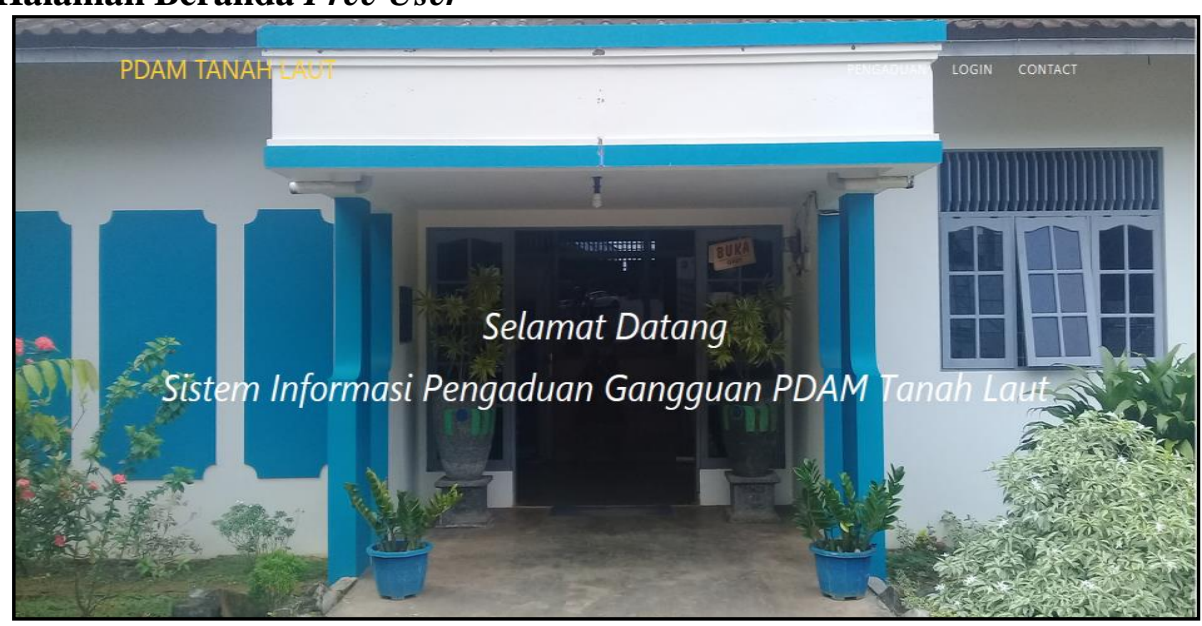

Gambar 5. Halaman beranda free user

Gambar 5 merupakan rancangan antar muka free user yang menunjukan 3 tampilan yang pertama menunjukan menu, bagian kedua menunjukan pelayanan dan bagian ketiga menunjukan tentang perusahaan. 


\subsubsection{Halaman Login}

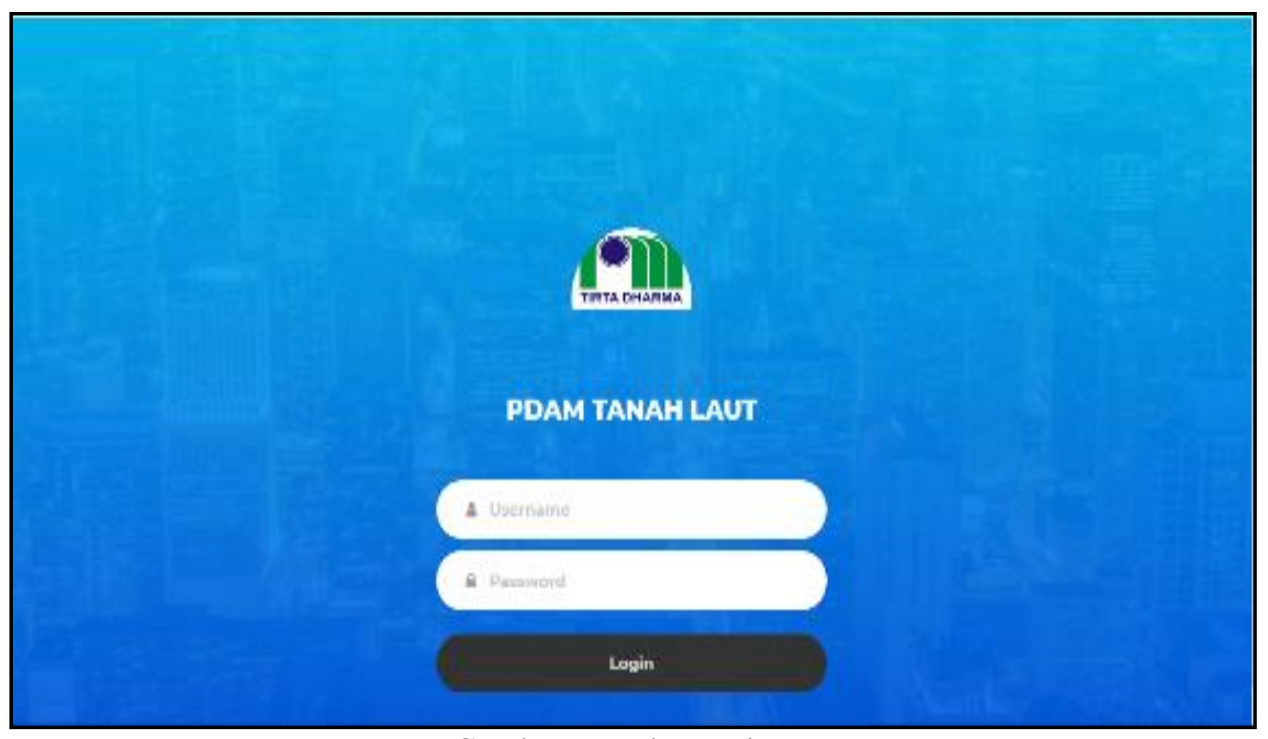

Gambar 6. Halaman login

Gambar 6 merupakan halaman login, dimana terdapat menu login hanya dapat dilakukan oleh bagian HUBLANG (admin), bagian teknik dan bagian TRANDIS.

\subsubsection{Halaman Pengaduan Free User}

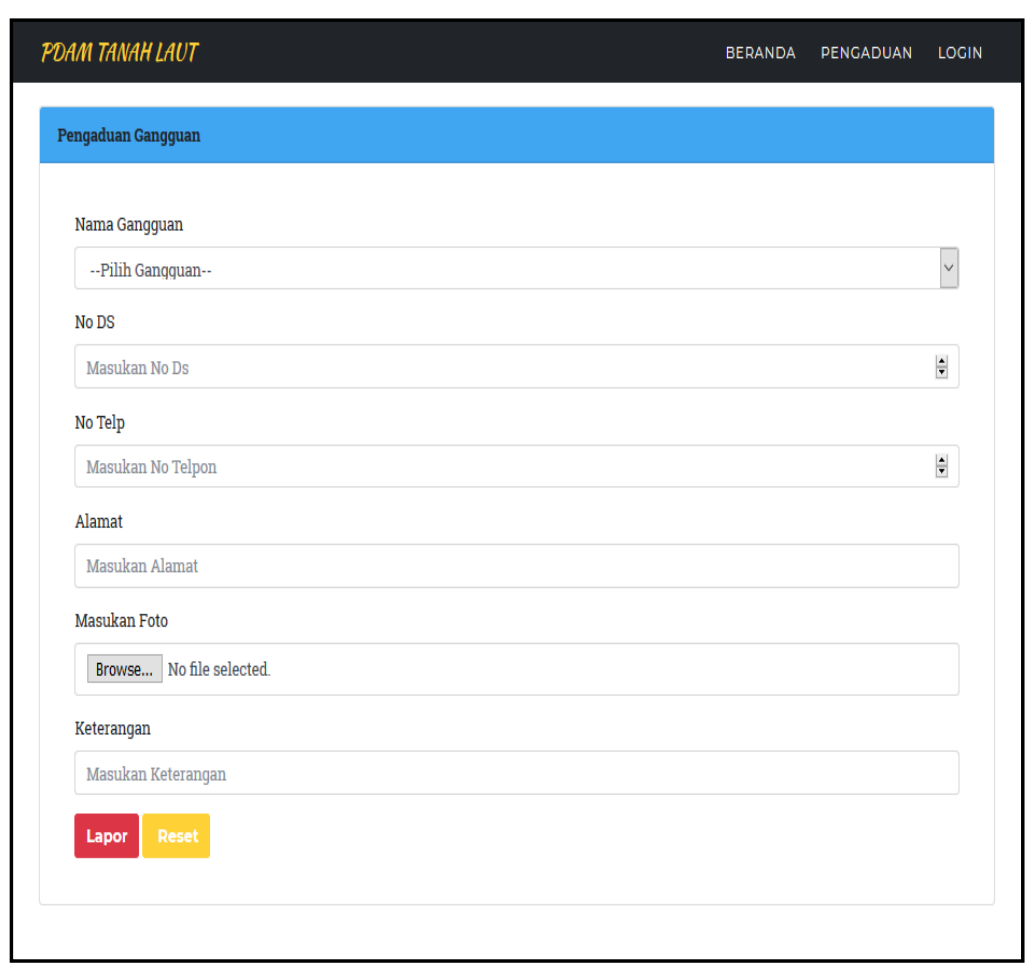

Gambar 7. Halaman pengaduan free user

Gambar 7 di atas merupakan halaman yang digunakan oleh free user (pelanggan) untuk menginputkan gangguan yang terjadi. Free user menginputkan gangguan yang terjadi kemudian data tersebut disimpan. Setelah data disimpan maka data akan tampil pada bagian hubungan langganan. 


\subsubsection{Halaman Pengaduan Bagian HUBLANG}

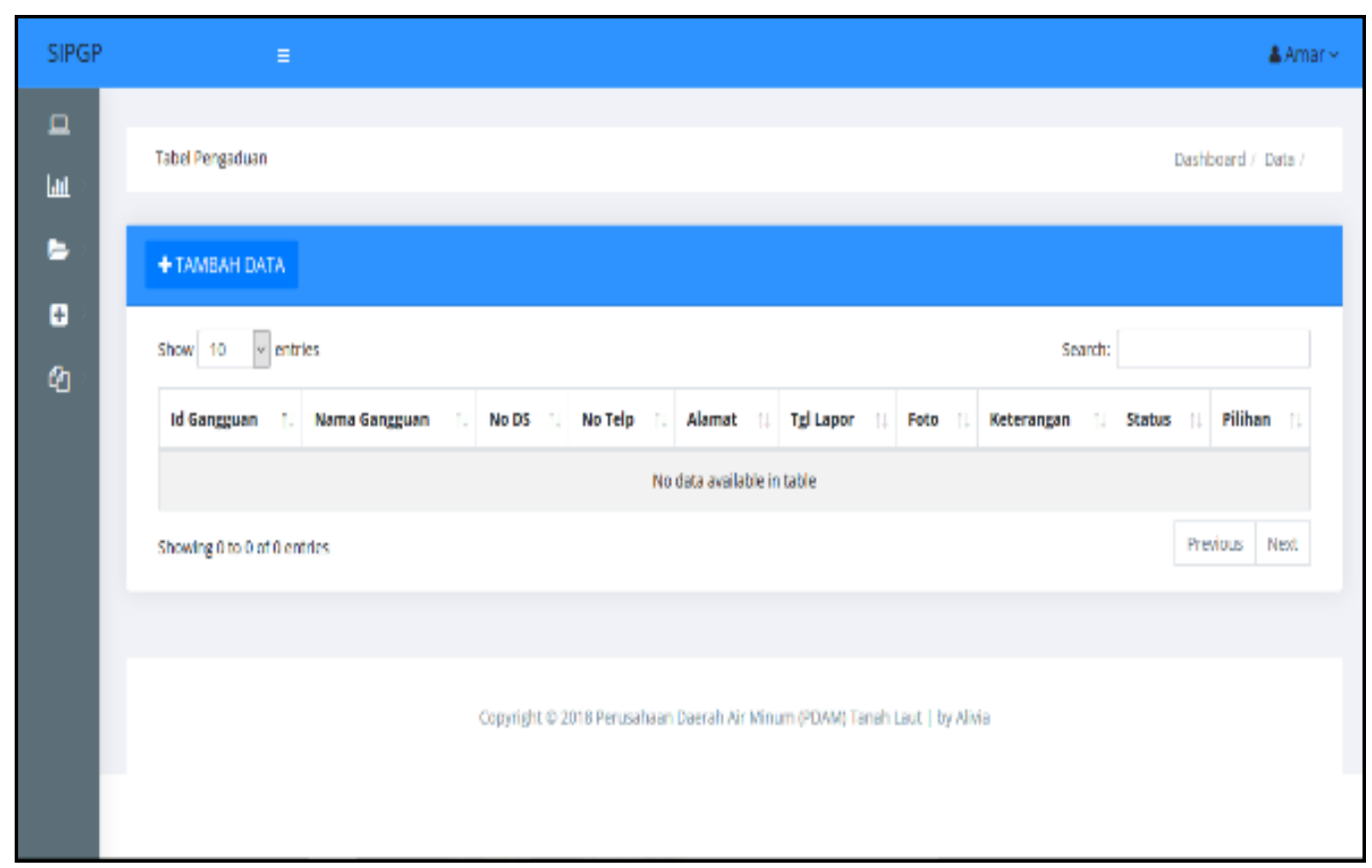

Gambar 8. Halaman pengaduan bagian HUBLANG

Gambar 8 merupakan halaman pengaduan pada bagian HUBLANG. Pada tabel pengaduan akan menampilkan id gangguan, nama gangguan, nomer DS, nomer telpon, alamat, tanggal lapor, foto, keterangan, status dan pilihan.

\subsubsection{Halaman Pengajuan Bagian HUBLANG}

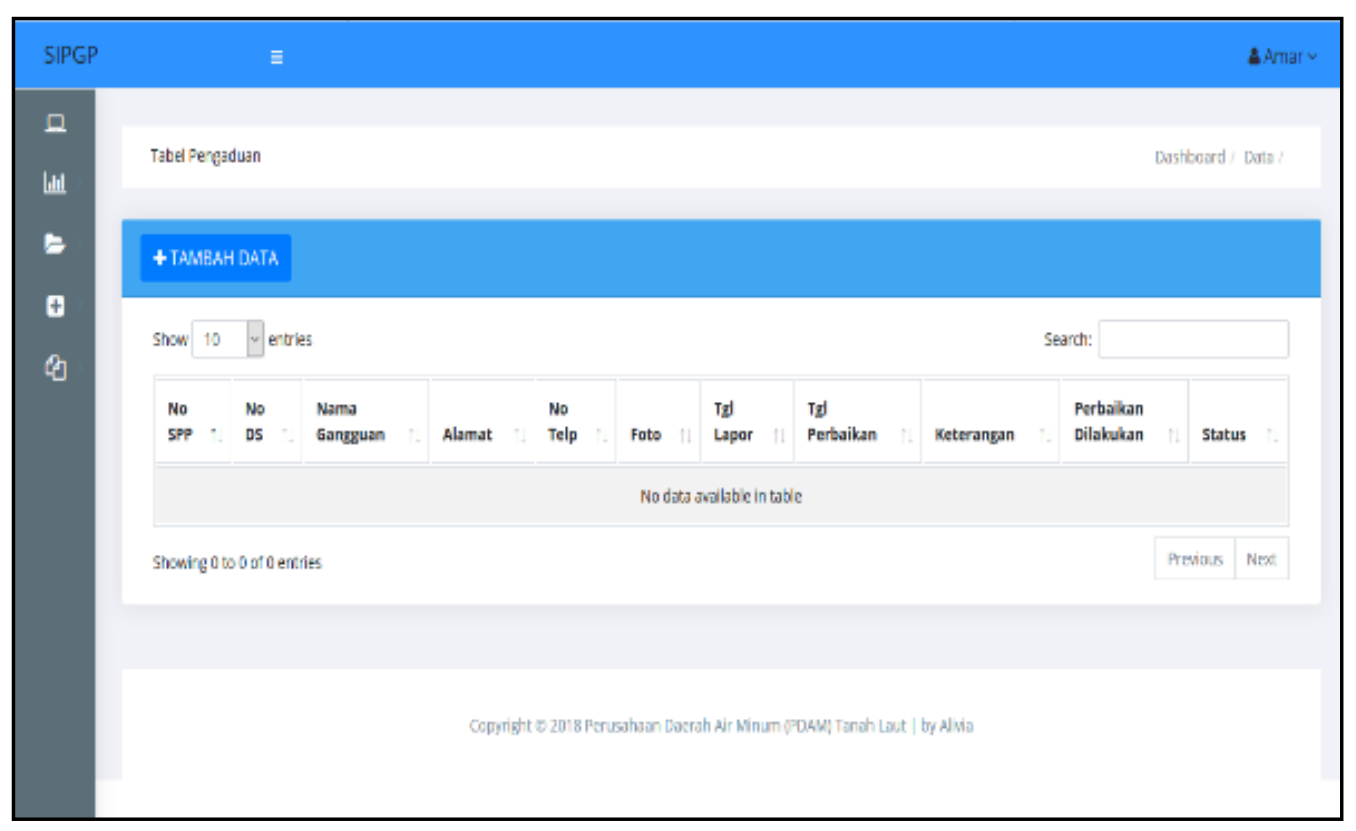

Gambar 9. Halaman Pengajuan bagian HUBLANG

Gambar 9 merupakan halaman pengajuan bagian HUBLANG. Bagian HUBLANG dapat menambahkan SPP pada tabel pengajuan. Pada tabel pengajuan dapat terlihat tiga status yaitu status proses 1 , proses 2 dan selesai. 


\subsubsection{Halaman Gangguan Bagian Teknik}

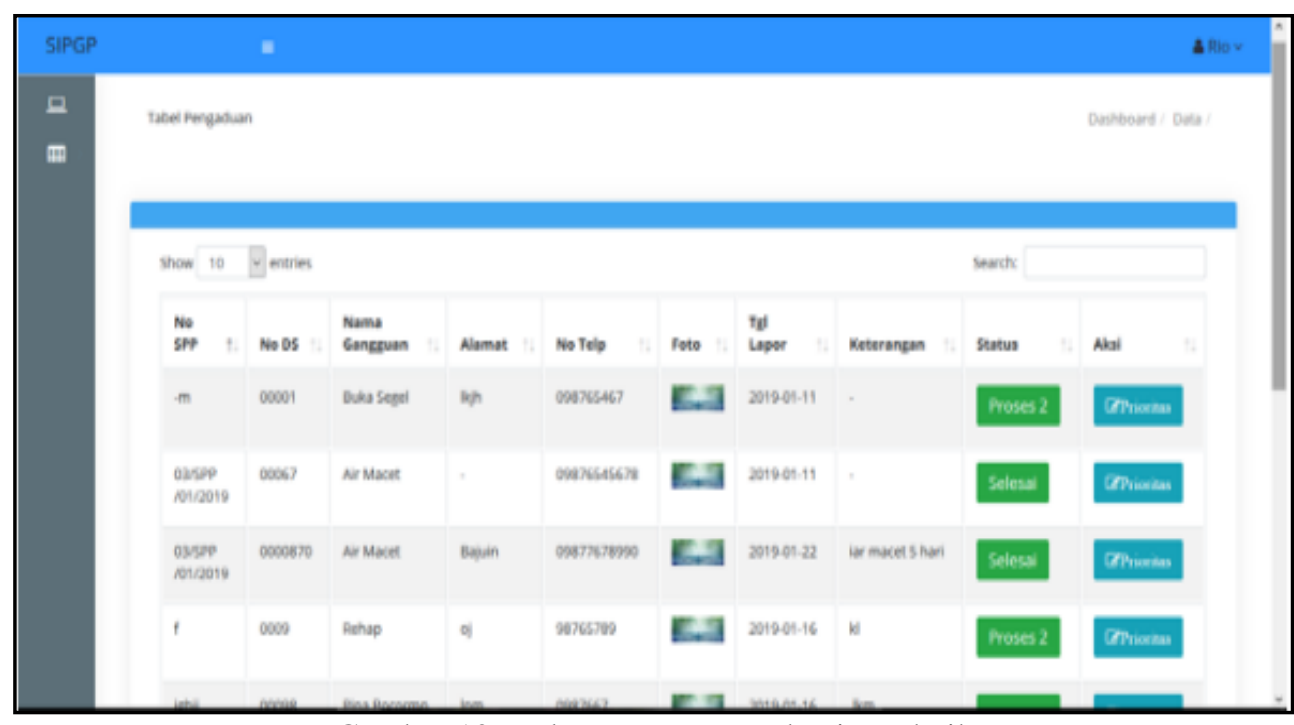

Gambar 10. Halaman gangguan bagian teknik

Gambar 10 merupakan tabel pengaduan pada bagian teknik. Pada tabel pengaduan terdapat data gangguan yang dikirim oleh bagian HUBLANG. Bagian teknik dapat menentukan skala prioritas pada halaman ini.

\subsubsection{Halaman Gangguan Bagian TRANDIS}

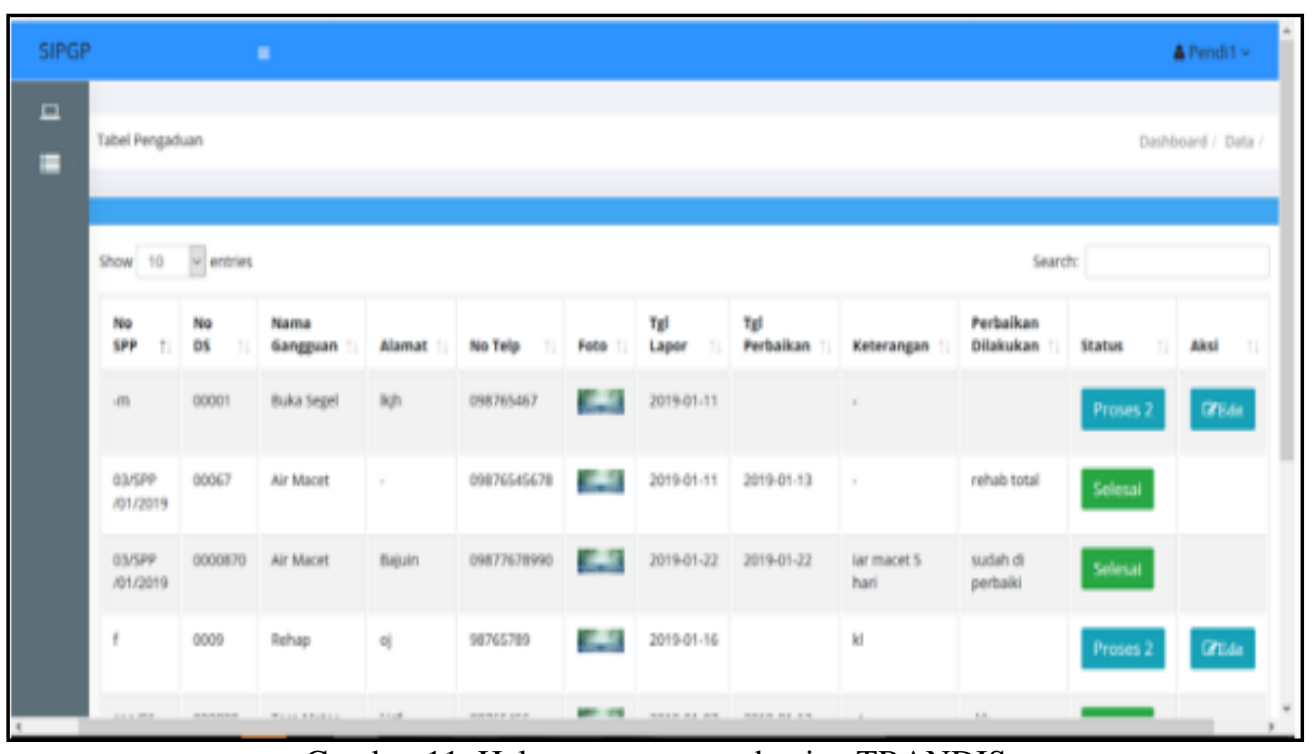

Gambar 11. Halaman gangguan bagian TRANDIS

Gambar 11 merupakan tabel pengaduan pada bagian TRANDIS. Pada halaman ini bagian TRANDIS dapat melihat informasi gangguan yang diberi skala prioritas. Kemudian bagian trandis dapat mengisikan tanggal perbaikan dan perbaikan yang dilakukan dari setiap data gangguan yang didapatkannya. 


\subsection{Pengujian Sistem}

Penulis melakukan pengujian Sistem Informasi Pengaduan Gangguan PDAM Tanah Laut Berbasis Web dengan menggunakan pengujian blackbox testing. Hasil pengujian yang dilakukan dapat dilihat pada tabel berikut.

Tabel 1. Hasil pengujian blackbox pada sistem informasi gangguan PDAM Tanah Laut

\begin{tabular}{|c|l|l|c|}
\hline No. & \multicolumn{1}{|c|}{ Kasus Uji } & \multicolumn{1}{c|}{ Hasil Pengujian } & Kesimpulan \\
\hline 1 & Validasi login & $\begin{array}{l}\text { Login berhasil dilakukan untuk semua } \\
\text { level user }\end{array}$ & Diterima \\
\hline 2 & Pengaduan pelanggan & $\begin{array}{l}\text { - Halaman pengaduan untuk free user } \\
\text { dimunculkan dan isi pengaduan } \\
\text { berhasil tersimpan di database. } \\
\text { - } \begin{array}{c}\text { Data pengaduan tampil pada halaman } \\
\text { pengaduan bagian HUBLANG. }\end{array}\end{array}$ & Diterima \\
\hline 3 & Pembuatan SPP & $\begin{array}{l}\text { Bagian HUBLANG dapat menambahkan, } \\
\text { merubah dan menghapus SPP melalui } \\
\text { halaman pengajuan }\end{array}$ & Diterima \\
\hline 4 & $\begin{array}{l}\text { Tampil SPP dan pemberian } \\
\text { skala prioritas oleh bagian } \\
\text { Teknik }\end{array}$ & $\begin{array}{l}\text { Bagian teknik dapat melihat data SPP } \\
\text { beserta gangguan yang diadukan. } \\
\text { Bagian teknik dapat memberikan skala } \\
\text { prioritas pada setiap data gangguan. }\end{array}$ & Diterima \\
\hline 5 & $\begin{array}{l}\text { Kelola data gangguan oleh } \\
\text { bagian Trandis }\end{array}$ & $\begin{array}{l}\text { Bagian trandis dapat melihat data } \\
\text { gangguan yang telah diberikan skala } \\
\text { prioritas. } \\
\text { Bagian trandis dapat menginputkan } \\
\text { tanggal perbaikan dan perbaikan yang } \\
\text { dilakukan pada data gangguan. }\end{array}$ & Diterima \\
\hline
\end{tabular}

Berdasarkan hasil pengujian blacbox, dapat disimpulkan bahwa semua fungsionalitas utama dapat berjalan dengan baik.

\section{KESIMPULAN}

Sistem Informasi Pengaduan Gangguan PDAM Tanah Laut berbasis web telah berhasil dikembangkan. Database pada sistem informasi ini dirancang dengan menggunakan ERD, sementara aliran datanya dirancang dengan menggunakan DFD. Pengujian blacbox yang dilakukan menyatakan bahwa seluruh fungsionalitas dari sistem ini dapat berjalan dengan baik.

\section{DAFTAR PUSTAKA}

Almuqsitu, A. B., Tursina, T., \& Sukamto, A. S. (2019). Rancang Bangun Aplikasi Pelayanan Pelanggan PDAM Tirta Kapuas Berbasis Web. Jurnal Sistem Dan Teknologi Informasi (JUSTIN), 7(1), 13-19.

Boylle, B. A. M., \& Arninputranto, W. (2014). Sistem Informasi Pengaduan Dengan Web Responsive di PT Pelabuhan Indonesia III Cabang Tanjung Perak. JURNAL ELTEK, 12(2), 53-64.

Firmansyah, C., \& Tohir, C. (2018). Sistem Layanan Pengaduan Masyarakat Lingkup Desa Gunungtanjung Berbasis Web dan SMS Gateway dengan Metode Antrian FIFO. Jurnal Manajemen Dan Teknik Informatika (JUMANTAKA), 1(1), 201-210.

Ibrahim, W. H., \& Maita, I. (2017). Sistem Informasi Pelayanan Publik Berbasis Web Pada Dinas Pekerjaan Umum Kabupaten Kampar. Jurnal Ilmiah Rekayasa Dan Manajemen Sistem Informasi, 3(2), 17-22.

Kadir, A. (2014). Pengenalan Sistem Informasi Edisi Revisi. Yogyakarta: Andi.

Nofyat, N., Ibrahim, A., \& Ambarita, A. (2018). Sistem Informasi Pengaduan Pelanggan Air Berbasis Website Pada PDAM Kota Ternate. Indonesian Journal on Information Systems, 
$3(1), 10-19$.

Pratama, A. Y., Prabowo, I. A., \& Normassari, A. (2017). (ALPUKAT) Aplikasi Pengaduan Masyarakat untuk Melaporkan Kejadian Pungutan Liar di Kabupaten Kudus Berbasis Android. Simetris: Jurnal Teknik Mesin, Elektro Dan Ilmu Komputer, 8(2), 399-404.

Sukamto, R. A., \& Shalahuddin, M. (2016). Rekayasa Perangkat Lunak (Terstruktur dan Berorientasi Objek). Bandung: INFORMATIKA.

\section{Biodata Penulis}

Alivia Agiesta Novitasari, lahir di Sungai Bakar pada tanggal 06 September 1997. Penulis pertama menyelesaikan Sekolah Menengah Kejuruan pada tahun 2016 dan melanjutkan pendidikan ke Politeknik Negeri Tanah Laut. Penulis pertama menempuh 6 semester (D-III) di Jurusan Teknik Informatika Politeknik Negeri Tanah Laut.

Wan Yuliyanti, penulis kedua memperoleh gelar Sarjana Pendidikan (S.Pd)) pada Studi Pendidikan Bahasa Inggris dari Universitas Tanjungpura Pontianak dan menyelesaikan Magister Pendidikan (M.Pd) pada Program Studi yang sama dari Universitas Palangka Raya. Menjadi dosen Bahasa Inggris di Politeknik Negeri Tanah Laut sejak 2009 pada Program Studi Teknik Informatika sampai saat ini (2019) 